\title{
A Survey of Patients with Substance Use Disorders at Government Treatment Facilities in The Bahamas
}

\author{
K Christie, N Clarke, M Frankson
}

\begin{abstract}
Objective: To determine the sociodemographic information and characteristics of patients aged 18-60 years diagnosed with substance use disorders presenting to the three government treatment facilities. To determine the prevalence rates of alcohol, cannabis, cocaine and poly-substance use disorders in patients presenting to government treatment facilities.

Methods: The Structured Clinical Interview for Diagnostic and Statistical Manual of Mental Disorders fourth edition, text revision (DSM-IV-TR) Axis 1 disorders was the first instrument used to screen for drug abuse or dependence. Additional questionnaires included a sociodemographic questionnaire and the Survey of Addicted Patients in Treatment Centres Standardized Questionnaire.

Results: The number of participants interviewed in the study was 120 people; $89.2 \%$ were males and $10.8 \%$ were females. The mean age of all participants with substance use disorders was 36.22 (10.74) years and they were predominantly male (8 to 1). Males were mostly single, unemployed or casually employed, of middle school education and were residents of New Providence. Alcohol, cannabis and cocaine were the common drugs that were misused. Of cocaine users, 52 (82.5\%) met the DSM-IV-TR criteria for dependence and of cannabis users, 20 (18.9\%) met the DSM-IV-TR criteria for abuse.

Conclusions: There is a need to conduct community surveys on school children, other adult populations eg in the wider community and on other island populations to determine the population rates of substance use disorders. Once the needs have been identified through research for the different islands and target groups, informed decisions can be made as to the allocation of financial and human resources.
\end{abstract}

Keywords: Abuse, community surveys, dependent, illicit, poly-substance, prevalence, psychiatric, treatment

\section{Estudio de Pacientes con Trastornos por Uso de Sustancias en Centros Gubernamentales de Tratamiento en Las Bahamas}

\author{
K Christie, N Clarke, M Frankson
}

\begin{abstract}
RESUMEN
Objetivo: Determinar la información sociodemográfica y las características de los pacientes en edades de 18-60 años diagnosticadas con trastornos por uso de sustancia, que acuden a los tres centros gubernamentales de tratamiento de la drogadicción. Determinar la tasa de prevalencia de los trastornos por uso de alcohol, cannabis, cocaína y polisustancias en los pacientes que acuden a los centros de tratamiento del gobierno.

Métodos: La Entrevista clínica estructurada para el diagnóstico y el Manual estadístico de trastornos mentales, cuarta edición, texto revisado (DSM-IV-TR), trastornos del eje 1, fue el primer instrumento utilizado para detectar el abuso o dependencia de drogas. Los cuestionarios adicionales incluyen un cuestionario sociodemográfico así como la llamada Encuesta de pacientes adictos en el cuestionario estandarizado de los centros de tratamiento.

Resultados: El número de participantes entrevistados en el estudio fue de 120 personas; 89.2\% eran varones y 10,8\% eran hembras. La edad promedio de todos los participantes con trastornos por uso de sustancias fue $36.22(10,74)$ años y eran predominantemente masculinos (8 a 1). Los varones eran
\end{abstract}

From: School of Clinical Medicine and Research, The University of the West Indies, The Bahamas.
Correspondence: Dr K Christie, P.O Box SP-60131, Nassau, New Providence, The Bahamas. E-mail: kirkchristie@gmail.com 
en su mayoría solteros, desempleados, o trabajadores eventuales, de nivel educacional medio, y residentes de Nueva Providencia. Alcohol, cannabis y cocaina fueron las comúnmente las sustancias del uso adictivo. De los consumidores de cocaina, 52 (82,5\%) correspondian a los criterios del DSM$I V$-TR con respecto a la dependencia, y de los consumidores de cannabis, 20 (18,9\%) correspondian a los criterios de DSM-IV-TR en relación con el abuso de sustancias.

Conclusiones: Es necesario llevar a cabo encuestas comunitarias con niños en edad escolar, otras poblaciones adultas - por ejemplo en la comunidad en general y en otras poblaciones de la isla - para determinar las tasas poblacionales de trastornos por uso de sustancias. Una vez que las necesidades hayan sido identificadas mediante investigación de las diferentes islas y los grupos seleccionados como objetivos, pueden tomarse decisiones informadas en cuanto a la asignación de las finanzas y recursos humanos.

Palabras claves: Abuso, encuestas comunitarias, dependiente, ilícitas, polisustancias, prevalencia, psiquiátrico, tratamiento

West Indian Med J 2013; 62 (7): 611

\section{INTRODUCTION}

The Commonwealth of The Bahamas is an archipelago of some 700 islands, rocks and cays with a landmass of 5382 square miles scattered over an area of 80000 square miles. Of the 700 islands, only 23 are inhabited. In 2007, the population estimate for The Bahamas was 305655 with almost $60 \%$ of the population residing on New Providence which includes the capital city of Nassau.

In the late 1970s and early 1980s, the trans-shipment of cocaine through the islands increased, due to its increased profitability as compared to similar sized shipments of marijuana. Consequently, cocaine trafficking through The Bahamas became firmly established and the country became a major point of trans-shipment of illicit substances (1).

The negative impact of cocaine became apparent when compensation changed from money to drugs, which were then sold on the local market. As vast quantities of cocaine passed through the islands, increasingly larger portions remained behind for local consumption. Cocaine use at this point progressed to the more addictive smoking of free-based cocaine. The resulting effect of this was an increase in the local cadre of pushers, abusers and dependents and a rapid increase in admission rates to the treatment and rehabilitation facilities (1).

There was a reported dramatic increase in the use of cocaine in its freebase form by the end of 1980, and during 1981-1983, the use of cocaine continued to gain popularity. Evidence suggested that this was due to the increase of cocaine trans-shipment through the islands of The Bahamas. Hospital statistics of 1982 and 1983 showed that the majority of patients presenting themselves for rehabilitation were males between the ages of 18 and 30 years of age (1). During this period of drug trans-shipment through the islands, excessive alcohol use was also evident in The Bahamas.

Before 1980, a study was conducted on drinking practices in The Bahamas. The Bahamian Drinking Practices Survey of 1969 showed that of 290 individuals sampled (120 males and 170 females), 69\% (50\% males and 50\% females) drank within the past 12 months and of this group, $42 \%$ drank greater than once per month (2). It was further reported that the highest proportion of heavy drinkers was found in the $30 \mathrm{~s}$ and 40 s year age groups. The group surveyed indicated that they drank, either because others around them were celebrating or to simply forget their worries or to help them relax (2).

A secondary school survey conducted in 2002 that included 1492 public students and 730 private students revealed that the average age of first use of substances was 11.2 years for males and 11.9 years for females. Overall, the results of this survey showed that alcohol is the most popular drug among students and marijuana appears to be the most used illicit substance $(3,4)$. Moreover, it was evident from the survey that cocaine usage in the form of cocaine powder or crack cocaine was very low among students $(3,4)$.

Marijuana became more available in The Bahamas in the late 1960s and early 1970s. It was smuggled via The Bahamas en route to South Florida. By the mid to late 1970s, marijuana became easily available on the local market (3). Cannabis consumption rates for the Caribbean region ranges from $4.3 \%$ to $6.7 \%$ of the population aged $15-64$ years (5). Similarly, cocaine consumption rates for the Caribbean region range from $0.7 \%$ to $1.0 \%$ of the population aged $15-$ 64 years (5). The results of a survey to assess the prevalence of illicit drug use among high school students in Jamaica over a four-week period in April-May 1995 revealed the prevalence rates were: marijuana, $10.2 \%$, cocaine, $2.2 \%$, heroin, $1.5 \%$ and opium, $1.2 \%$. The proportions of male students who used marijuana, cocaine, heroin and opium were significantly higher than those of their female counterparts (6).

A cross-sectional study of adolescents in the Caribbean region representing a collaborative effort between the ministries of health in nine countries, the Pan American Health Organization (PAHO) and the World Health Organization (WHO) and nine Caribbean Community and Common Markets (CARICOM) countries revealed the 
following results on alcohol and other drug use: alcohol was the most commonly used substance on a monthly or a more frequent basis (females $3.9 \%$, males $7.9 \%$ ), followed by marijuana [females $1.2 \%$, males $2.3 \%$ ] (7). The percentage of adolescents reporting use of any substances, monthly or more often was $10.6 \%$, with the highest rates among males and older adolescents (7).

There are limited available treatment options for persons with substance use disorders in The Bahamas. The agencies engaged in the rehabilitation of individuals with substance use disorders in The Bahamas include the Community Counselling and Assessment Centre (CCAC) which is the government outpatient mental health facility. The drug rehabilitation programme at CCAC provides acute and follow-up care for persons with substance use disorders in an outpatient setting (8).

The Detoxification Unit was established in 1992 to serve as the unit for acute drug related admissions prior to transfer of patients to the Lignum Vitae Unit (inpatient facility). The problem with substance misuse continues to escalate in The Bahamas as demonstrated by an increase in the number of referrals to the inpatient and outpatient government treatment facilities $(9,10)$.

This research seeks to gain access to this population with the use of standardized instruments in order to get an objective view of the present situation. The compilation, analysis and comparison of the data with other countries in the Caribbean region facing similar problems will benefit The Bahamas.

Specific objectives were:

* to determine the sociodemographic information and characteristics of patients diagnosed with substance use disorders presenting to the three government treatment facilities, and

* to determine the prevalence rates of alcohol, cannabis, cocaine and poly-substance use disorders in patients presenting to government treatment facilities.

\section{SUBJECTS AND METHODS}

This is a cross-sectional study. The researcher did a sample survey of the population hoping to achieve a sample size of 144 subjects. A 95\% confidence interval (95\% CI) was sought and around proportions we calculated the sample size using a $\mathrm{z}$ value of 1.96 (rounded to 2.0 ) with the assumption that the typical usage of substances was about $90 \%$. The patients who presented to the CCAC and patients admitted to Sandilands Rehabilitation Centre (SRC) for drug treatment over a six-month period were screened for possible inclusion in this study. The patients included in this study were a convenience sample of eligible subjects who gave informed consent.

Inclusion criteria included subjects between the ages of 18 and 60 years meeting the Diagnostic and Statistical
Manual of Mental Disorders fourth edition, text revision (DSM IV-TR) Axis 1 disorders criteria for substance abuse or substance dependence, admitted to the Detoxification Unit at SRC and those seen at the CCAC. Exclusion criteria included participants less than 18 years of age and greater than 60 years of age and any participant diagnosed with dementia or who was acutely psychotic at the time of the interview. Participants not fulfilling DSM-IV-TR criteria for substance abuse or dependence were also excluded from the study.

The study was approved by the Public Hospital Authority-University of the West Indies Ethics Committee (PHA-UWI-EC) of The Bahamas. Written consent was obtained from each subject after the researcher explained, as stated on the form, the reason for the study and the voluntary and confidential nature of the study. The signing of the consent form was witnessed and the participant received a copy of it.

After informed consent from the participant, the Structured Clinical Interview for DSM-IV-TR (SCID) was the first instrument used to screen for drug abuse or dependence $(11,12)$. Once the substance use disorder criterion was met then the following instruments were administered:

* Sociodemographic questionnaire (self-administered version)

* Survey of Addicted Patients in Treatment Centres Standardized Questionnaire [SAPTCSQ; InterAmerican Uniform Drug Use Data System, 2001] (face to face interview)

A pilot study involving ten participants from the Detox Unit who gave written informed consent was undertaken before commencement of the research.

Information from the SCID-1 patient score sheet, sociodemographic questionnaire and SAPTCSQ was coded and entered into the Statistical Package for the Social Sciences (SPSS) version 17 for Windows. The data were double entered so as to enhance the internal validity of the study by removing data entry information bias/errors. The researcher received assistance from a qualified statistician/ epidemiologist to manage the data and generate statistics from the entered data.

Descriptive statistics concerning quantitative and qualitative data for the sample as a whole were calculated and reported. Frequency distributions of several variables, be they quantitative variables or those for qualitative data, were obtained by simple frequency tables and cross-tabulations allowing further assessment by the various levels of some other variable of interest (13).

\section{RESULTS}

The number of participants interviewed in the study was 120 . The subjects' mean $( \pm \mathrm{SD})$ age was $36( \pm 10.74)$ years while the median (IQR: Q1, Q3) age was 37 (IQR: Q1 = 27,Q3 = 45) years. 
Table 1: Treatment centre and type, referral source and work status by gender

\begin{tabular}{|c|c|c|}
\hline Variables & $\begin{array}{l}\text { Male } \\
\text { n (\%) }\end{array}$ & $\begin{array}{c}\text { Female } \\
\text { n (\%) }\end{array}$ \\
\hline \multicolumn{3}{|l|}{ Island of residence } \\
\hline New Providence & $89(83.2 \%)$ & $12(92.3 \%)$ \\
\hline Grand Bahama & $8(7.5 \%)$ & $1(7.7 \%)$ \\
\hline \multicolumn{3}{|l|}{ Treatment centre } \\
\hline CCAC & $39(36.4 \%)$ & $3(23.1 \%)$ \\
\hline Detox Unit & $51(47 \%)$ & $8(61.5 \%)$ \\
\hline LVU & $17(15.9 \%)$ & $2(15.4 \%)$ \\
\hline \multicolumn{3}{|l|}{ Treatment type } \\
\hline Outpatient & $39(36.4 \%)$ & $3(23.1 \%)$ \\
\hline Inpatient & $68(63.6 \%)$ & $10(76.9 \%)$ \\
\hline \multicolumn{3}{|l|}{ Referral source } \\
\hline Voluntarily & $45(42.1 \%)$ & $10(76.9 \%)$ \\
\hline Court order & $40(37.4 \%)$ & $2(15.4 \%)$ \\
\hline \multicolumn{3}{|l|}{ Work status } \\
\hline Permanently employed & $28(26.2 \%)$ & $1(7.7 \%)$ \\
\hline Casually employed & $21(19.6 \%)$ & $1(7.7 \%)$ \\
\hline Unemployed & $44(41.1 \%)$ & $10(769 \%)$ \\
\hline
\end{tabular}

$\mathrm{CCAC}=$ Community Counselling and Assessment Centre; $\mathrm{LVU}=$ Lignum Vitae Unit

Table 2: Substance use disorders and their frequencies and percentages

\begin{tabular}{rc}
\hline Substance use disorders & $\begin{array}{c}\text { Overall frequency } \\
\text { and valid per cent } \\
\text { n (\%) }\end{array}$ \\
\hline Alcohol use disorders (LP) & $12(10.5 \%)$ \\
Abuse & $69(60.5 \%)$ \\
Dependence & $20(18.9 \%)$ \\
Cannabis use disorders (LP) & $63(59.4 \%)$ \\
Abuse & $1(0.8 \%)$ \\
Dependence & $52(82.5 \%)$ \\
Cocaine use disorders (LP) & $63(52.5 \%)$ \\
Abuse & 14 \\
Dependence & \\
Poly-substance disorders & \\
Poly-substance dependence & \\
(defined by DSM-IV-TR) & \\
\hline
\end{tabular}

\section{DISCUSSION}

From this study, it is evident that young males and females of mean $( \pm \mathrm{SD})$ age $36.22(10.74)$ years are receiving treatment at government facilities for drug abuse. The males outnumber females 8 to 1 . Some likely reasons for the small number of women presenting for treatment are (i) women with children experience more shame than men and worry about losing custody of their children and failing to fulfil childcare responsibilities (14), (ii) females are 20 times as likely as men to receive opposition from family and friends regarding treatment entry (14) and (iii) females are being told that they are intrinsically bad if they dare admit to a substance use problem and further that they are not only damaging themselves but creating irreversible damage to their progeny (14). The majority of the participants in the study lived on the two most populated islands of New Providence, 101 (84.2\%) and Grand Bahama, 9 (7.5\%) [Table1]. Overall, in the study, 54 (45\%) were unemployed, 22 (18.3\%) were casually employed and only $29(24.2 \%)$ were permanently employed (Table 1). The high percentage of unemployed in this study was suggestive of the negative social effects of substance use, including the ability to secure and maintain a job. For those meeting the criteria for substance dependence, alcohol, $69(60.5 \%)$ was the second most prevalent (Table 2$)$. This prevalence rate is no surprise owing to the fact that in The Bahamas, alcohol is a deeply engrained staple of the Bahamian cultural heritage, as its use is associated with having a good time $i e$ in parties and celebrations.

In the study, cannabis abuse is the most prevalent and possible reasons for this include (i) attitudes to the drug: most adolescents and young adults in The Bahamas view it as a safe substance that will not result in any undesirable effects. Moreover, despite being an illicit substance, it is a popular and a culturally acceptable substance that is commonly used by adolescents and young adults, (ii) availability: the general feedback from patients is that cannabis is a cheap drug that is readily available.

Of those who met the criteria for dependence, cocaine dependence $(82.5 \%)$ was the most prevalent (Table 2). Possible reasons for this finding include the "high" associated with crack cocaine which is perceived as being more intense than with other drugs eg cannabis or alcohol [acute rewarding properties] $(15,16)$. Another possible reason for the presence of poly-substance disorders $(52.5 \%)$ as seen in the study, specifically with regards to persons who misuse crack cocaine, is that there are many undesirable side effects associated with its use and so crack cocaine misusers use cannabis and alcohol to come off the "high" (Table 2).

The CCAC in New Providence needs to be improved upon in order to make it more "female friendly" by providing caretakers who are primarily responsible for supervizing children of mothers being referred to and/or receiving treatment at the facility during the operational hours of 8 am to $4 \mathrm{pm}$. Another recommendation is that community based studies be conducted eg school surveys on the family islands and in the wider communities of New Providence. Once the needs have been identified through research for the different islands and target groups, informed decisions can be made as to the allocation of financial and human resources. This could stimulate initiatives for training of medical and allied health professionals in techniques for intervention, treatment and rehabilitation for drug misuse disorders. The development and implementation of programmes geared to meet the needs of individuals with substance use disorders in their communities should be prioritized. Evidence based treat- 
ment will also promote early identification (with the use of screening instruments ie NM-ASSIST) and intervention (17).

Limitations of the study include (i) possible reporter bias on the self-administered questionnaire, (ii) results may not be repre-sentative of and generalizable to the general population as the study was conducted on special target populations (patients who were treatment seeking).

\section{REFERENCES}

1. Clarke N. Drug abuse 1975-1985: the cocaine crisis: clinical perspectives of the Bahamian experience of illegal substances. New York: Plenum Publishing Corporation; 1987: 133-7.

2. Dean-Patterson S. A longitudinal study of changes in Bahamian drinking 1969-1977. Dissertation presented at Florence Hellen Graduate School, Brandeis University, Waltam Massachusetts; 1978: 614, 38-41, 42-5, 56-61, 94-125, 131-48,164-88, 214-223.

3. Bahamas Ministry of Health. Bahamas drug information system annual national report, 2001 [Internet]. 2003 [cited 2009 Jan 01]; Available from: www.unodc.org/pdf/barbados/bahamas_drug_report_2001.pdf

4. Bahamas Secondary School Drug Prevalence Survey of 2003 [Internet]. 2003 [cited 2009 Jan 01]; Available from: http://www.rbpf.org/ nadsbahamas.org/Pdf/School_D

5. World Drug Report of 2009. Results from the United Nations Office on Drugs and Crime [Internet]. 2009 [cited 2010 Mar] Available from: http://www.unodc.org/documents/wdr/WDR_2009/WDR2009_eng_we b.pdf

6. Soyibo K, Lee MG. Use of illicit drugs among high school students in Jamaica. Bull World Health Org 1999; 77: 258-62.

7. Halcon L, Blum RW, Beurhring T, Pate E, Campbell-Forrester S, Venema A. Adolescent health in the Caribbean: a regional portrait. Am J Public Health 2005; 38: 214-29.
8. Clarke N, Dean-Patterson S. Women, substance abuse and AIDS in the Bahamas: an overview. Bahamas: Sandilands Rehabilitation Centre; 2000: 23-33, 41-4.

9. Medical Records Department, Sandilands Rehabilitation Centre. Annual statistics of Sandilands Rehabilitation Centre, 2002-2008. Admissions and Discharge log book; 2010 [retrieved 2010 Feb]. Fox Hill, New Providence.

10. Health Information and Research Unit, Ministry of Health. Annual statistics from the Community Counselling and Assessment Centre, 1990-2006. [retrieved 2008 Dec]. Meeting Street, New Providence.

11. First MB, Spitzer RL, Gibbon M, Williams JB. User's guide for the structured clinical interview for DSM-IV axis-1 disorders clinical version. $7^{\text {th }}$ ed. Virginia: American Psychiatric Publishing, Inc; 2002; 1 132

12. First MB, Spitzer RL, Gibbon M, Williams JB. User's guide for the structured clinical interview for DSM-IV axis-1 disorders research version [Internet]. 2008 Oct [cited 2009 Aug]; Available from: www. scid4.org

13. Goutham R. Rational medical decision making: a case based approach. United States of America: The McGraw Hill Companies, Inc; 2007: 7$61,129-145$.

14. Coupe J, Glass B, eds. The international handbook of addiction behaviour. London: Routledge; 1991: 168-174.

15. Kalivas PW, Volkow ND. The neural basis of addiction: pathology of motivation and choice. Am J Psychiatry 2005; 162: 1403-13.

16. Hyman SE. Addiction: a disease of learning and memory. Am J Psychiatry 2005; 162: 1414-22.

17. National Institute on Drug Abuse. Screening for drug use in general medical settings: quick reference guide [Internet]. NIH publication no 09-7384; 2009 [cited 2010 May 01]. Available from: http://www. drugabuse.gov/sites/default/files/pdf/screening_qr.pdf; http://www. who.int/substance_abuse/activities/assist_v3_english.pdf 